\title{
Scenekunstens (for)handlingsrom etter 22. juli
}

\author{
Siemke Böhnisch
}

\begin{abstract}
In this article I discuss theatre's scope of action after the 2011 terror attacks in Norway (" 22. July"), with an emphasis on independent theatre, aesthetic heteronomy and the public sphere. A theatre manager's (Jon Refsdal Moe) retrospect account of and reflections upon a case of selfcensoring is the starting point for my (re-)examination of the arguments and dynamics concerning some of the most prominent contentious 22. July performances. I discuss how the controversies can be understood and dealt with, and how they are connected to theatre's scope of action and place in society today. In my argument, I differentiate between the public sphere as an arena for discussion and debate (which theatre, as an institution, more or less has lost its impact on), and the public, conceived as an imagined community (which theatre still is strongly connected to, as assigned a publics' symbolic space). I argue that the controversies about the 22 . July performances, as well as the usage of marginal spaces, have to be understood as part of a farreaching cultural dynamics after the terror attacks, concerning not only the arts, but numerous sectors of society, and that the performances aesthetic heteronomy requires a work- and context specific approach.
\end{abstract}

Keywords: Independent theatre, 2011 Norway attacks, scope of action, aesthetic heteronomy, public sphere

\section{Om forfatteren}

Siemke Böhnisch (*1964) er professor i teater ved Universitetet i Agder (UiA). Hun forsker på samtidsteater og teater i kontekst. Hennes forskning beveger seg i skjæringsfeltet mellom forestillingsanalyse, systematisk teaterteori og aktuelle samfunnsperspektiver. Böhnisch har publisert en lang rekke vitenskapelige artikler og fagartikler. Forskningsartikkelen «Å gi Breivik en scene? Scenekunst etter 22. juli» (publisert i Ekfrase 1/2014) har blitt kåret til Årets beste tidsskriftartikkel 2014. Siemke.Bohnisch@uia.no

Teatervitenskapelige studier 2019 C) Siemke Bönisch

Nummerredaktører: Anette Therese Pettersen og Elisabeth Leinslie

Medredaktør: Julie Rongved Amundsen. For TVS: Ragnhild Gjefsen

Ansvarlig redaktør: Tor Bastiansen Trolie - tor.trolie@,uib.no

Publisert av Teatervitenskap, Institutt for lingvistiske, litterære og estetiske studier, Universitetet i Bergen

Bergen Open Access Publishing - https://boap.uib.no/index.php/tvs

ISSN: 2535-7662

Manusutviklingen av disse artiklene er støttet av: Danse- og teatersentrum, Norsk Kulturråd, Kristiansand kommune, Fritt Ord, BIT teatergarasjen, Dramatikkens hus, Bergen kommune. 


\section{Scenekunstens (for)handlingsrom etter 22. juli}

\section{«Fri ytring under press»}

Ved høstseminaret til Norsk teaterlederforum i oktober 2015 talte Jon Refsdal Moe, daværende teatersjef ved Black Box teater i Oslo, om «Fri ytring under press». Seminaret hadde tittelen «Ytringsfrihet, (selv)sensur og teatersjefens 'redaktøransvar'». I Refsdal Moes innlegg er kontroversene om kunst etter 22. juli blant beleggene for «at kunstens eget rom, kunstens handlingsrom, blir pressa litt på alle bauger og kanter». ${ }^{1}$ Interessant i den sammenheng er hans beretning om selvsensur fra hans virke som teatersjef ved Black Box teater i Oslo, en hendelse som ikke hadde vært kjent i offentligheten tidligere. ${ }^{2}$ Han forteller at han avsto fra å sette opp et gjestespill av Milo Raus Breiviks Erklärung $(2012)^{3}$ - en av de internasjonalt fremtredende fri scenekunstproduksjoner om terrorangrepet 22. juli - «fordi jeg visste at det ville bli et hælvete [!], og jeg ville ikke belaste de etterlatte mer for å forsvare et prinsipp». ${ }^{4}$

Denne episoden kan leses på bakgrunn av et mer omfattende fenomen, beskrevet i rapporten Nar kunstnere vurderer ytringsfribet i Norge, anno $2014:^{5}$

Hendelsene 22. juli 2011 framstår som et vendepunkt. Så mange som 17 prosent [av de spurte kunstnerne, S.B.] kjente sin ytringsfrihet berørt av «ettervirkninger fra hendelsene 22. juli 2011» og enda flere mente framveksten av politisk ekstremisme hadde innskrenket ytringsfriheten. [...] Inntrykket er [...] at det er offentligheten og ytringskulturen rundt kunsten [...] som innskrenkes. Det er konsekvensene av å ytre seg, tiltakende tendenser til «politisk korrekthet» i samfunnet og et økende antall situasjoner der særskilte grupper gjør spesielle krav gjeldende overfor kunstneriske ytringer, som oppleves som problematisk. ${ }^{6}$

Det finnes en rekke velkjente eksempler på et høyt konfliktnivå rundt kunst etter 22. juli, på teaterfeltet med Christian Lollikes/CaféTeatrets Manifest 2083 (2012) og den nevnte produksjonen til Milo Rau/IIPM fra samme år, på det visuelle feltet med debatten om Morten Viskums The Clown (2012), avvisningen av Vanessa Bairds KORO-prosjekt for regjeringsbygget R6 og striden om Johan Dahlbergs Memory Wound, den kunstneriske utformingen av det opprinnelig planlagte, men til slutt kansellerte 22. juli-minnesmerket på Sørbråten ved Utøya. Førstnevnte og de to sistnevnte brukes da også som cases i den siterte ytringsfrihetsrapporten. ${ }^{7}$

Handler slike konflikter om en manglende «lukning i forhold til de andre offentlige diskursene», en mangel på anerkjennelse av kunstens egenverdi, av «kunstneriske ytringer som frie ytringer» slik Refsdal Moe tolker det, ${ }^{8}$ eller handler det om at det finnes temaer som det ikke går an å ta opp i kunsten uten å blande seg (eller bli dradd inn) i det offentlige ordskifte? Men har kunsten da et eget handlingsrom? Hvem har i så fall ansvar for å opprettholde det? Og hvilken plass har den frie scenekunsten i den sammenheng? Har den et eget frirom, slik selve betegnelsen ser ut til å implisere? 


\section{(Selv-)sensur, definisjonsmakt og visningsarenaer}

Refsdal Moe fremstiller sin avgjørelse om ikke å vise Milo Raus Breiviks Erklärung på Black Box teater som et eksempel på selvsensur. Det er et rimelig perspektiv når han taler som teatersjef til andre teaterledere. I den sammenheng handler det om hans handlingsrom som kunstnerisk leder. Sett utenifra kan den samme episoden derimot fremstå som en form for sensur. Som leder av ett av de tre største programmerende teatrene i Norge ${ }^{9}$ rådet Refsdal Moe over en meget sentral visningsarena for fri scenekunst. De færreste scenekunstnere innen fri scenekunst har et eget spillested, og de fleste er derfor avhengige av å få tilgang til egnede visningsarenaer.

Programmerende teatre i Norge er ikke bare utstyrt med romlige, tekniske og personelle ressurser for å vise den frie scenekunsten, men også med en veletablert institusjonell definisjonsmakt innenfor feltet. Å få antatt sin produksjon på et av disse teatrene konstituerer eller bekrefter faglig anerkjennelse, og garanterer samtidig en distribusjon til et spesifikt publikum. I et av teatrenes egne ord: «BIT er et såkalt programmerende teater. [...] Det vil si at de forestillingene du finner på vårt program er valgt av vår teatersjef på bakgrunn av forestillingenes kunstneriske kvalitet.» ${ }^{10}$ De programmerende teatrene inngår i det som teaterviter Melanie Fieldseth analyserer som «strukturelle omgivelser for fri scenekunst» i Norge. ${ }^{11}$ I den forstand er den frie scenekunsten selvfølgelig også et institusjonelt bundet kunstfelt.

Når Refsdal Moe avstår fra å vise Breiviks Erklärung handler det åpenbart ikke om manglende kunstnerisk kvalitet, og heller ikke om at produksjonen ikke passer inn i teaterets profil. ${ }^{12}$ Tvert imot, med kjennskap til feltet må Black Box teater sies å være en av de mest opplagte visningsarenaene i Norge for et gjestespill av Milo Raus produksjoner. Teateret har en uttalt internasjonal profil som inngår i og bidrar til den generelle internasjonale orienteringen i det frie scenekunstfeltet, ${ }^{13}$ og den sveitsiske scenekunstneren med sin label IIPM (International Institute of Political Murder) har i mange år vært høyt anerkjent internasjonalt. Da en av Raus tidligere produksjoner ble vist i Norge, var det nettopp på Black Box teater. Hate Radio, en dokumentarteaterproduksjon om folkemordet i Rwanda, ble programmert som del av Oslo Internasjonale Teaterfestival 2013 av Refsdal Moe. Og teateret var også spillested for et annet av Raus verk i 2016, da Five Easy Pieces ble vist som del av prosjektet MOToffentlighet. ${ }^{14}$

\section{Hensyn å ta}

Refsdal Moe sier at han ikke viste Breiviks Erklärung «[f]ordi jeg visste at det ville bli et hælvete, og jeg ville ikke belaste de etterlatte mer for å forsvare et prinsipp». ${ }^{15}$ Forestillingen, som kan beskrives som en form for reenactment av terroristens forklaring i retten, har skapt sterke reaksjoner mange steder i Europa. Sascha Ö. Soydan, en tysk kvinnelig skuespiller med innvandrerbakgrunn fra Tyrkia, leser opp terroristens tekst på scenen, foran et kamera og et tilstedeværende publikum. Tilskuerne bevitner opplesningen og filmingen, de ser både skuespilleren og videobildet på scenen. Etterpå følger en paneldiskusjon med regissør, skuespiller og utvalgte gjester, før diskusjonen til slutt åpnes for publikumsdeltakelse. ${ }^{16}$

Sannsynligvis ville en avgjørelse for å vise Breiviks Erkärung på Black Box teater i Oslo fått stor oppmerksomhet i media, langt ut over den vanlige scenekunstoffentligheten. En offentlig 
kontrovers hadde neppe uteblitt. Og det er ingen tvil om at en slik situasjon kunne ha blitt en stor belastning for mange av de etterlatte og overlevende, samt - ikke minst - for medarbeiderne på Black Box teater, inkludert Refsdal Moe selv. Det er tungtveiende hensyn å ta. Jeg har tidligere argumentert for at scenekunstnere som tematiserer 22. juli på teaterscenen, må ta med $\mathrm{i}$ betraktning de etterlattes og overlevedes perspektiv og stemmer, men at det ikke kan være det enerådende perspektivet. ${ }^{17}$ Argumentet om ikke å belaste de direkte rammede har i mange sammenhenger blitt ritualisert, og kommer nærmest som en refleks som stopper videre diskusjon og avveining av ulike hensyn mot hverandre. I verste fall skyves det påståtte hensynet foran for å unngå krevende, men nødvendige kontroverser og debatt.

\section{Å bety noe utenfor kunstens lukkede univers}

Refsdal Moe spør i sitt foredrag for teatersjefene: «Hvorfor får vi ikke være i fred lenger?»» ${ }^{18}$ forhold til de konkrete casene han omtaler, er det kanskje en forstålig reaksjon, men i et historisk perspektiv, med tanke på at den frie scenekunsten en gang søkte seg ut av de lukkede institusjonene, er det et tankevekkende spørsmål. Hva har skjedd med ønsket om å bety noe for verden utenfor (scene)kunstens lukkede univers? Refsdal Moe er selvfølgelig ikke fri fra den agendaen. Både når han påpeker at et manglende forsvar av kunst som fri ytring «[i]kke bare er et kunst-problem, men et demokratisk problem», og når han retorisk spør: «Om ikke i kunsten, hvor da? Hvor kan man leke med potensielle virkeligheter? Hvor kan man stille spørsmålene som ikke lar seg stille i fornuftig samtale? Som overskrider grensene for hva det er mulig å snakke om? $\rangle^{19}$ Argumentasjonen hans impliserer at verdien av slike overskridelser nettopp ikke er kunstintern.

Øystein Stene, dosent ved teaterhøyskolen i Oslo, skrev få dager etter 22. juli terrorangrepet: «Vi har vel aldri etter 1945 vært i en mer endevendende emosjonell og kollektiv prosess, hvor alle sånn til de grader synes å ha behov for å delta.» ${ }^{20}$ Alle - det er «folk flest», men også kunstnerne. ${ }^{21}$ Mange kunstnere som har bidradd med kunst etter 22. juli, har fremhevet dette sterke personlige behovet, et opplevd samfunnsansvar for å bidra i de kollektive prosessene etter 22. juli.

\section{Mediestorm rundt Manifest 2083}

Men selv om forpliktelsen overfor en kollektiv prosess anføres, kan det se ut som om det gjelder andre og strengere (uskrevne) regler for kunsten enn for andre felt. Refsdal Moe påstår at «kunstfeltet var det eneste samfunnsfeltet der det ikke var lov til å diskutere Anders Behring Breivik». ${ }^{22}$ Han henviser i den sammenheng til den meget opphetede debatten i den norske offentligheten om Christian Lollikes Manifest 2083, produsert av CaféTeatret i København i 2012. Vi kan tilføye at debatten var like heftig i Danmark, og at medieomtalen og -skandaliseringen spredte seg til mange land i og utenfor Europa. Mediestormen startet nærmest umiddelbart etter at CaféTeatret i januar 2012, et halvt år etter terrorangrepet, offentliggjorde sin beslutning om å lage en monologteaterforestilling basert på gjerningsmannens såkalte manifest. Allerede lenge før premieren i oktober 2012 hadde Manifest 2083 blitt til en av de mest omtalte og omdiskuterte produksjonene i dansk teaters historie. Den ekstraordinære mediedekningen hadde til og med blitt utstilt på teatermuseum før forestillingen hadde premiere. ${ }^{23} \mathrm{Og}$ konflikten utspilte seg ikke 
bare i massemediene. Teatret og kunstnerne bak forestillingen mottok hatmeldinger og trusler som førte til at dansk politi måtte vurdere behov for fysisk beskyttelse rundt premieren.

I Norge fikk debatten om Manifest 2083 fort en egen vri. Etter at flere kunst- og kulturpersoner hadde blitt sitert i media med svært kritiske uttalelser om CaféTeatrets planer, gikk Kai Johnsen, daværende kunstnerisk leder ved Dramatikkens hus i Oslo, offentlig ut med en støtteerklæring for Lollike og hans prosjekt. Han tilbød også direkte hjelp i produksjonsprosessen, og det ble på et tidspunkt snakk om en slags dobbelpremiere, først i København, så i Oslo på Dramatikkens Hus. Siden Johnsen på den måten aktivt oppsøkte en posisjon som medansvarlig scenekunstner, ble han og Dramatikkens hus også part i saken. ${ }^{24}$ Samtidig gikk representanter for den Nasjonale støttegruppen etter 22. juli ut i media med et ønske om å stanse hele prosjektet, mens enkelte direkte berørte sto offentlig frem med sin frustrasjon over støttegruppens forsøk på å utøve sensur overfor teatre og andre offentlige aktører i deres navn. ${ }^{25}$ Konfliktlinjene var altså kompliserte, likevel kunne det oppstå et hovedinntrykk av en bred front mot og en sterk fordømmelse av CaféTeatrets prosjekt i offentligheten. Temperaturen i saken var gjennomgående svært høy, fyrt opp av medienes fokus på konflikt og skandale.

Debatten ble for øvrig også ført i en mer spesifikk scenekunstoffentlighet, som i debattartikler og i kommentarfeltet til den norske nettavisen for profesjonell scenekunst scenekunst.no. Noen debattanter forsøkte i den sammenheng å nyansere eller revidere inntrykk som hadde oppstått gjennom den skandaliserende og konfliktorienterte dekningen i massemediene, men tonen kunne bli like opphetet, om enn ikke verre også innad i den mer avgrensede scenekunstoffentligheten.

Den samlede mediedynamikken ble kanskje forsterket av de mange konfliktarenaene og involverte parter. Massemediene hadde åpenbart en aktiv rolle, og det kunne være interessant å undersøke konflikten rundt Manifest 2083 nærmere som en transnasjonal medieskandale. ${ }^{26}$ Poenget $i$ vår sammenheng er at scenekunstens handlingsrom var direkte berørt av medienes dekning av saken. Og det er rimelig å anta at mediestormen rundt Manifest 2083 skapte en slags presedens - eller, nærmere sagt, et skrekkscenario - for fremtidige forsøk på å ta opp 22. juli på teaterscenen. Slik leser jeg Refsdal Moes henvisning til denne casen i sammenheng med sin egen avgjørelse om ikke å vise Breiviks Erklärung på Black Box teater.

\section{Er kontroversene et tegn på manglende lukning?}

Kontroversene rundt Breiviks Erklärung er mindre kjent i Norge. Produksjonen hadde premiere 19. oktober 2012 i Weimar/Tyskland, kun fire dager etter premieren til Manifest 2083 i

København. ${ }^{27}$ Kontroversene manifesterte seg spesielt i forestillingens institusjonelle kontekst. Det er en fri scenekunst-produksjon uten eget spillested. I forste omgang ble den vist ulike steder i Tyskland, Sveits og Østerrike, men siden også i andre europeiske land.$^{28}$ Breiviks Erklärung ble som regel spilt bare én gang på ett og samme sted. Ved flere av disse anledningene ble den utestengt fra de (kunst)stedene som først hadde annonsert visningen - med etterfølgende skandalisering i media. Det skjedde allerede ved premieren i oktober 2012. Opprinnelig annonsert som gjestespill ved det velrennomerte institusjonsteatret Deutsches Nationaltheater Weimar, måtte den bli flyttet til et alternativt spillested, en kinosal (Lichthaus Kino i Weimar), på meget kort varsel. 
Kontroversene om Manifest 2083 og Breiviks Erklärung kan tolkes dithen at de, på et generelt plan, handler om hva scenekunsten kan og ikke kan, får lov og ikke får lov, i forhold til så voldsomme og traumatiske hendelser som terrorangrepet 22. juli. Mer spesifikt handler de om bruken av de valgte tekstdokumentene og om forholdet til gjerningsmannen. Breiviks Erklärung er i sin helhet basert på forklaringen som gjerningsmannen ga under rettsprosessen i Oslo Tingrett, nærmere bestemt på hovedforhandlingens andre dag, 17. april 2012. Manifest 2083 anvender Breiviks såkalte manifest, det 1500-siders tekstkompendiet med tittelen 2083 - A European Declaration of Independence, som gjerningsmannen sendte ut elektronisk til over 1000 mottakere få timer før bombeangrepet i Oslo. Innvendingen ligger klart i dagen: I disse tekstene prøver gjerningsmannen å rettferdiggjøre angrepet og spre sitt ideologiske budskap. Den sentrale anklagen mot de to forestillingene lyder derfor på at de gir massemorderen en scene, at de gjør seg til et talerør for terroristen.

Jeg har tidligere analysert og kommentert disse kontroversene inngående, ${ }^{29}$ og vil her, med hensyn til spørsmålet om scenekunstens handlingsrom, drøfte Refsdal Moes antakelse om at fordømmelsen av forestillingene er et tegn på en manglende «lukning i forhold til andre offentlige diskurser», en mangel på anerkjennelse av «kunstens egenverdi», av «kunstneriske ytringer som frie ytringer». ${ }^{30} \mathrm{Jeg}$ mener at denne argumentasjon blir problematisk vis-à-vis de konkrete forestillingene. Å kreve eller å forvente at Breiviks Erklärung eller Manifest 2083 skal tolkes og forstås «løsrevet fra et generelt offentlig ordskifte» eller «ordinære meningssammenhengen tar ikke høyde for forestillingenes estetikk og agenda. De dokumentariske strategiene, fremfor alt de valgte tekstdokumentenes indeksikalske funksjon, ${ }^{31}$ kobler det som skjer på teaterscenen eksplisitt til den konkrete utenomkunstneriske virkeligheten, inkludert det generelle offentlige ordskifte om 22. juli. Dette er forestillinger som ikke legger opp til en tolkning eller opplevelse som er løsrevet fra meningssammenhenger utenfor teatersalen, tvert imot. Det blir derfor meningsløst å ønske at de skal kunne forstås «på bakgrunn av seg selv», ikke som del av en «større helhet». ${ }^{32}$

\section{Heteronomi-estetikk}

På et generelt plan handler dette om at en heteronomi-estetikk ikke kan forsvares med autonomiestetiske ideer om et lukket og adskilt kunstrom og med kunstens egenverdi løsrevet fra verdenen denne kunsten prøver å gripe inn i. Om man ønsker å imøtegå fordømmelsen Breiviks Erklärung og Manifest 2083 har blitt møtt med, burde det skje kontekst- og verkspesifikt. Da er man nødt til å gå inn i forestillingene, lese de komplekse utsigelseskontruksjonene og å relatere dem til de utenomkunstneriske kulturelle, sosiale og politiske prosessene. ${ }^{33}$

For å komme tilbake til Refsdal Moe, er det opplagt et tynt grunnlag å invitere Breiviks Erklärung for «å forsvare et prinsipp» ${ }^{34}$. Hvorfor går han ikke inn på hva denne forestillingen konkret gjør, kan og vil i den kulturelle og politiske konteksten forestillingen inngår i? Da ville han ha hatt mye mer tungtveiende grunner til å vise den på Black Box teater, eller i det minste for å avveie om det var verdt å vise den - veid opp imot andre, eventuelt motstridende hensyn, som til de direkte rammede etter 22. juli og til teaterets medarbeidere, inkludert ham selv. 


\section{Hvorfor ikke på teaterscenen?}

Samtidig er det forståelig at argumentasjonen for å forsvare forestillingene fort beveger seg til et prinsipielt nivå når man svarer på en fordømmelse som er meget generaliserende. Et fremtredende argument mot forestillingene er: Uansett hvordan tekstene til gjerningsmannen er tenkt anvendt på teaterscenen, skal de ikke brukes. Den sterke fordømmelsen kommer da også som regel fra personer som ikke har sett forestillingene, og som heller ikke ønsker å se dem.

Refsdal Moe påpeker et paradoks som har blitt fremhevet av mange som har prøvd å forsvare forestillingene: De brukte tekstene til gjerningsmannen er fritt tilgjengelig på nettet, og i tilfelle Breiviks forklaring i retten har de til og med blitt publisert av anerkjente massemedier uten at det har ført til protester i offentligheten. Hvorfor får ikke teateret bruke disse tekstene? Spørsmålet blir særlig påtrengende når man tar høyde for hvor begrenset distribusjon teaterforestillinger har sammenlignet med andre medier. Aftenposten når over en million lesere daglig. Manifest 2083 ble spilt på CaféTeatret i København for 48 tilskuere om gangen. Selv etter mange visninger forblir det totale antall tilskuere forholdsvis lite. Enda mindre distribusjon hadde forestillingen Breiviks Erklärung siden den som regel bare spilles én gang på hvert sted. Dessuten blir ingen eksponert for disse forestillingene med mindre de aktivt går inn for å kjøpe en billett og å oppsøke spillestedene - i motsetning til mediedekningen av 22. juli, som det var og er umulig å skjerme seg mot i dagens digitaliserte mediesamfunn.

Kontroversen har åpenbart ikke noe med den faktiske distribusjonen å gjøre. Den handler om det rene og skjære faktum at disse teaterforestillingene skulle bli produsert og vist på teaterscenen. ${ }^{35} \mathrm{I}$ den norske scenekunstoffentligheten har det ofte blitt nevnt at det handler om en misoppfattelse av teater som et medium for ren underholdning. Det er ingen tvil om at striden blant annet handler om hva teater som medium og kunstform er og kan være i dagens samfunn. Men underholdnings-hypotesen griper for kort. Den kan ikke svare på de to sentrale spørsmålene: Hvorfor er det tilsynelatende farligere å bruke gjerningsmannens tekster på teaterscenen enn at de ligger fritt tilgjengelig på nettet? Og hva vedkommer disse forestillingene folk som ikke oppsøker dem, og som til og med gjør et poeng ut av at de aldri kommer til å se dem?

\section{Scenekunstens (selv-)marginalisering i offentligheten}

Som regel er det i dag av relativt liten interesse for den allmenne offentligheten hva som foregår på teaterscenen. Teateret har for lengst mistet sin funksjon som sentral arena for allmenn offentlig diskurs og debatt, altså for den demokratiske offentligheten i spesifikk forstand. Denne funksjonen har blitt overtatt av andre medier, først av massemediene, så i tillegg av de sosiale digitale mediene. Ved siden av denne mediehistoriske utviklingen har scenekunstens modernistiske tilbaketrekning til et autonomt kunstrom, til black boxen i bokstavelig og overført forstand, blitt anført som årsak til marginalisering. Christopher B. Balme går i sin bok The Theatrical Public Sphere (2014) så langt å si at teatret har gitt opp eller forlatt sin offentlighetsstatus i den grad at forestillinger foregår i en kvasi-privat sfære, med svært lite relevans for den generelle offentligheten. ${ }^{36}$ Han skriver om «theatre's increasing marginality as an agent in the public 
sphere», om «the increasing social and political marginalization of theatrical performance as part of the wider public». ${ }^{37}$

Og det spørs om denne marginaliseringen ikke er enda mer alvorlig for den frie scenekunsten enn for andre deler av scenekunstfeltet. Når det i det frie feltet som regel ikke så mye er et spørsmål om hvorvidt man får en god eller dårlig kritikk, men om man overhodet får en kritikk, er det et tegn på en ekstrem marginal posisjon i offentligheten. I tillegg til denne usynliggiøringen i dagens mediesamfunn kommer et mer selvskapt problem når den frie scenekunsten først og fremst forholder seg til et innviet innsiderpublikum.

\section{Offentlighet som debatt vs. offentlighet som (forestilt) fellesskap}

For å forstå konfliktene rundt 22. juli-forestillingene må vi ta høyde for at selv om teateret har mistet sin plass som sentral arena for den demokratiske offentligheten, forblir det et offentlig sted, og det har, ikke minst, beholdt status som offentlighetens symbolske sted ${ }^{38}$. Selv om de avgjørende debattene ikke skjer på teateret, og selv om det konkret samlede publikum ikke er representativt for den generelle offentligheten, så kan det fremdeles symbolisere offentligheten. Jeg antar at det henger sammen med teaterinstitusjonens historie og scenekunstens spesifikke medialitet. Publikum og aktørene må være ko-presente ${ }^{39}$ for at forestillinger kan finne sted, for at aktørenes handlinger på scenen kan bevitnes av publikum i salen. Teaterets kollektive produksjon, distribusjon og resepsjon, knyttet til et konkret fysisk sted gjør at det oppstår en anskuelig mikro-offentlighet, en ansikt-til-ansikt-situasjon, som både kan oppleves innenifra og tolkes utenifra som offentlighetens symbolske sted. Dermed kan det som foregår i teatersalen fremstå som - i emfatisk forstand - offentlig, det vil si bevitnet av allmennheten, på vegne av dem som ikke er tilstede.

Til forskjell fra offentlighet som diskurs og debatt handler det her om offentlighet som et (forestilt) fellesskap ${ }^{40}$, jf. David Wiles' distinksjon mellom teater som medium for å artikulere debatter versus teater som medium for å danne fellesskap. ${ }^{41}$ «In the German idiom, is it a tool for Gesellschaft or Gemeinschafte.» ${ }^{42}$ I den grad teateret fremdeles har status som et av offentlighetens symbolske steder, er det forståelig at selve faktumet at Breiviks tekster brukes på en teaterscene, bevitnet av et tilstedeværende publikum, vedkommer også dem som ikke er tilstede. Samtidig blir det klart hvorfor det kan oppfattes som mye farligere å bruke disse tekstene på teaterscenen enn at de ligger fritt tilgjengelig på nettet. Det handler ikke om distribusjonens kvantitet, men om dens antatte kvalitet. Inngår tekstene i en fremføring på en teaterscene, er det som om allmennheten lytter til og dermed implisitt godkjenner tekstene - en slik implikasjon ligger ikke i offentliggjøring som skriftlig referat på internett.

Skandalen ligger dessuten i scenekunstens kroppsliggjøring. Kanskje er det det verste tabu at noen kunne tenke seg å prøve «å være ham», bevitnet og dermed godtatt av et teaterpublikum. Det er langt ifra hva som skjer i Breiviks Erklärung, og selv i Manifest 2083 blir det først og fremst en teatral utprøving, ingen naturalistisk-realistisk dramatisering, ${ }^{43}$ men skandalen ligger ikke i hvordan forestillingene faktisk og konkret behandler materialet på scenen. Den ligger i ideen om hva bruken av tekstene på en teaterscene betyr for offentligheten, forstått som et forestilt fellesskap, til forskjell fra offentlighet forstått som arena for diskurs og debatt. 


\section{En reaktivering av teaterets offentlighet}

Man kan avvise protestene mot Manifest 2083 og Breiviks Erklärung som mistillit til teatermediet, basert på fantasien om forestillingene. Man kan også snu det og ta konfliktene rundt forestillingene som et tegn på at forestillingene engasjerer seg $i$ et kulturelt omkjempet - og dermed også samfunnsmessig relevant - felt. Ifølge Balme trengs det ikke nødvendigvis en skandale, men en slik skandale kan indikere at den teatrale offentligheten er reaktivert og koblet på den allmenne offentligheten, her forstått som arena for diskurs og debatt:

To what extent is the theatrical public sphere affected at all by the performance event? [...] [T] heatre in performance mode remains a realm of intensity, eliciting a wide variety of libidinal and affective as well as cognitive responses. The theatrical public sphere is affected when these intensities spill out of the auditorium and intervene in and engage with sensitive social discourses. ${ }^{44}$

Breiviks Erklärung og Manifest 2083 engasjerer seg i «kampen om fortellingen» ${ }^{45}$ etter terrorangrepet 22. juli. Det er i aller høyeste grad en «sensitive social discourse» ${ }^{46}$, særlig i Norge, men også i andre europeiske land. Hvem eller hva var under angrep 22. juli 2011 og hvorfor? Den norske offentligheten ble veldig fort fanget i en konsensus om at det var «en mot oss», «en mot Norge/allmennheten/demokratiet». ${ }^{47}$ Men hvem er «vi» når den som angriper «oss» er «en av oss $\rangle^{48}$ ?

\section{Trangere (for)handlingsrom etter 22. juli - ikke bare for kunsten}

Allerede i 2012 slo Norsk journalistlag fast at det hadde blitt «mindre åpenhet etter 22. juli»» ${ }^{49}$ Dette kom frem i en omfattende spørreundersøkelse blant norske journalister, presentert under markering av Pressefrihetens Dag i 2012. ${ }^{50}$ Journalistenes oppfattelse av eget handlingsrom blir bekreftet av nyere samfunnsvitenskapelig forskning som viser at pressens kritiske funksjon og muligheter for åpen debatt ble svekket etter 22. juli. ${ }^{51}$

Den nylig publiserte antologien Norge etter 22. juli: Forhandlinger om verdier, identiteter og et motstandsdyktig samfunn ${ }^{52}$ inneholder flere artikler som tematiserer at rommet for uenighet har generelt blitt mindre i den norske offentligheten etter 22. juli. ${ }^{53}$ Manglende rom for debatt må også ses i sammenheng med at tolkningsrommet etter terrorhendelsene var (og er) trang. Sosialantropologen Åshild Kolås slår i sin artikkel i ovenfor nevnte antologi fast at «the overwhelming social mobilization just after the attacks was followed by a hesitant political debate that was confined within narrow frameworks of understanding». ${ }^{54}$

I skrivende stund, syv år etter terrorangrepet, er det tydelige tegn på at dette trange tolkningsrommet har lagt lokk på viktige politiske debatter som, for eksempel, brøt seg frem i konflikten rundt et Facebook-oppslag til daværende justisminister Sylvi Listhaug (FRP) i mars 2018 som førte til at hun måtte trekke seg som justisminister. At disse debattene fremstår som særdeles farlig for den kollektive norske identiteten, henger sammen med hvordan det forestilte og opplevde fellesskapet etter 22. juli har blitt det dominerende perspektivet i den offisielle kulturelle responsen slik den for eksempel viser seg i utstillingen til 22. juli senteret i Oslo. ${ }^{55}$ 
Selv i norsk skole er temaet så og si tabubelagt. ${ }^{56}$ Når Det Europeiske Wergelandsenteret presenterer læringsressurser om 22. juli, ${ }^{57}$ finner vi materialet om «kontroversielle tema» som er definerte slik:

Kontroversielle tema beskrives ofte som konflikter eller problemer som er aktuelle, vekker sterke følelser og bidrar til motstridende forklaringer og løsninger avhengig av ulike overbevisninger, verdier og/eller konkurrerende interesser. De har derfor en tendens til å skape splid i samfunnet. Slike tema er ofte svært kompliserte og umulig å avklare bare ved å legge frem fakta. ${ }^{58}$

Kontrasten til de ikoniske bildene av rosetogene fra juli 2011 og av «folkehavet» syngende Barn av regnbuen fra april 2012, som har brent seg inn i den kollektive bevisstheten som symboler på det samlede «vì ${ }^{59}$ er slående. Debatten er farlig, fordi den tilsynelatende truer det opplevde og forestilte fellesskapet etter terrorangrepet.

\section{Marginale rom og flyktighet}

Teater som offentlighetens symbolske sted hvor det tilstedeværende publikum symboliserer det forestilte fellesskapet, er spesielt fremtredende ved etablerte og offentlig subsidierte teaterinstitusjoner, for eksempel ved Nationaltheatret hvor denne funksjonen allerede ligger i navnet. Å vise Milo Raus Breiviks Erklärung på Nationaltheatret hadde rett og slett vært utenkelig. Men i dette perspektivet er kanskje Black Box teater heller ikke det rette stedet? Selv om fri scenekunst oppsto med en impetus om å skape en mot-offentlighet, ${ }^{60}$ og det fri scenekunstpublikum i dag er en relativ lukket, og om ikke homogen, så i hvert fall ikke sosialt, kulturelt og politisk representativ, del-offentlighet, så er i dag de etablerte visningsarenaene for fri scenekunst nettopp: etablerte institusjoner.

Det er i denne sammenheng påfallende at fri scenekunst oppsøkte «ikke-teater-rom», gikk ut av black boxen, i bokstavelig og i overført forstand, inn i det jeg vil betegne som marginale rom sett ut fra scenekunstens institusjonaliserte rom - for å tematisere 22. juli.

Det gjelder for eksempel prosjektet Ikkje direkte råka av Maria Tryti Vennerød (2012), 22. julilesningen på Sakprosafestivlaen (2013), Kate Pendrys Points of Pain (2014) og Julian Blaues Scenefilosofisk. fakultet for kunstbasert terrorforskning (2014). Ikkje direkte råka var et sceneblogprosjekt som ble gjennomført parallelt med at rettssaken mot gjerningsmannen foregikk i Oslo Tingrett. Det ble realisert som en kombinasjon av en digital blogg, skrevet og publisert dag-for-dag av dramatikeren Maria Tryti Vennerød, mens rettssaken foregikk, ${ }^{61}$ og ukentlige sceniske lesninger på bokhandelen Halvbroren, Cappelen Damms bokhandel i Akersgata i Oslo, som involverte en rekke norske scenekunstnere. 22. juli-lesningen ble vist på Litteraturhuset under Sakprosafestivalen høsten 2013, og Kate Pendrys Points of Pain, som opprinnelig ble utviklet til Ytringsfrihetsfestivalen Red Zone i Beirut/Kairo (mai 2014), ${ }^{62}$ ble senere vist på Historisk Museum i Oslo (13. juni 2014) og på Ytringsfrihetsdagene på Litteraturhuset i Skien (22. oktober 2014). Julian Blaues performance fant sted som del av programmet til utstillingen Vi lever på en stjerne på Henie Onstad Kunstsenter i Bærum. Sistnevnte er selvfølgelig en meget etablert kunstinstitusjon, men ikke desto mindre et «ikke-teater-rom». Det kan se ut som at disse stedene var - i den gitte 
kulturelle situasjonen etter terrorangrepet 22. juli - mer egnet til å bearbeide 22. juli enn etablerte scenekunstvisningssteder, altså teatre, ${ }^{63}$ deriblant Black Box teater i Oslo. Fordelen med disse ikke-teater-stedene er at man slipper, eller demper, statusen som følger med etablerte teaterhus til å være offentlighetens symbolske sted.

I tillegg til at det oppsøkes marginale rom, er det et fellestrekk for de nevnte forestillingene og prosjektene at de vektlegger flyktigheten og skisseaktigheten til hendelsen. De fremstår ikke som formfullendte verk, men som desiderte utprøvinger (for eksempel som sceniske lesninger). I tillegg preges flere av de nevnte forestillingene av en markant selv-refleksivitet gjennom en verkintern forhandling om kunstens handlingsrom i forhold til 22. juli. ${ }^{64}$

\section{Eget (handlings-)rom?}

Har scenekunsten altså et eget handlingsrom? I min argumentasjon fremstår kunstens handlingsrom i forhold til 22. juli ikke som kunstens eget rom, løsrevet fra offentlig debatt eller kollektive kulturelle prosesser for øvrig. I de drøftede og omtalte casene er det kunsten selv som begir seg ut i verden gjennom spesifikke estetiske og dramaturgiske strategier. Dessuten er scenekunstens egne rom, $i$ ordrett forstand, altså de etablerte visningsstedene som vi kaller «teatre», underlagt historisk-kulturelle betingelser som knytter dem tett til offentligheten som forestilt fellesskap. Det gjelder ikke bare for institusjonsteatre, men også for etablerte visningsarenaer for fri scenekunst. Forskjellen mellom Black Box teater og Nationaltheatret er i den henseende ingen artsforskjell, bare en gradsforskjell.

Samtidig ligger det et handlingsrom i scenekunstens måter å kommunisere på. Når forestillinger handler om eller tar opp 22. juli, så forhandles vår tolkning og våre måter å forholde oss til hendelsene, inkludert gjerningsmannen. En slik forhandling er nødvendigvis kulturelt omstridt. «22. juli» er et kontroversielt tema ${ }^{65}$ - ikke bare i kunsten. Som vi har sett, fremstår tolknings- og debatt-rommet etter 22. juli som begrenset for mange samfunnsaktører og i mange samfunnsfelt. De omtalte forestillingene prøver å bidra til å utvide dette rommet.

For å gjøre det, trenger de fysiske steder - visningsarenaer. Det er påfallende at fri scenekunst som tematiserer 22. juli, i stor grad har oppsøkt marginale rom - sett ut ifra scenekunstfeltet. Denne selvmarginaliseringen har imidlertid en annen valør enn den som Balme omtaler ${ }^{66}$. Mens den modernistiske tilbaketrekning til et autonomt kunstrom bidrar til at scenekunsten mister relevans for den allmenne offentligheten, forstått som diskurs og debatt, er de her omtalte visningene på ikke-teater-steder et forsøk på å koble seg igjen på denne offentligheten.

Et sentralt punkt i min argumentasjon er at forestillinger som er preget av en heteronomiestetikk, ikke kan forsvares med autonomi-estetiske ideer om et lukket og adskilt kunstrom eller med kunstens generelle egenverdi. En avgjørelse om å vise en forestilling som Breiviks Erklärung kan og burde ikke begrunnes med «å forsvare et prinsipp» ${ }^{67}$. Gjennom en slik begrunnelse fraskriver man seg ansvar for en spesifikk kunstnerisk kvalitetsvurdering samt for å avveie ulike hensyn mot hverandre. Vi trenger kontekst- og verkspesifikke kvalitetsvurderinger og en avveining av motstridende hensyn - både for å forstå og for å opprettholde kunstens handlingsrom i dag. 


\section{Noter}

${ }^{1}$ Moe, «Fri ytring under press».

${ }^{2}$ Moes foredrag ble i etterkant av seminaret publisert på to nettsteder, først på NTO (Norsk Teater- og Orkesterforening) sin nettside, noen dager senere også på scenekunst.no. På scenekunst.no er teksten publisert som debattartikkel, men den utløste, så vidt jeg vet, ingen offentlig debatt.

${ }^{3}$ En produksjon av Milo Rau og IIPM. Min oversettelse av tittelen: Breiviks forklaring.

${ }^{4}$ Moe, «Fri ytring under press».

${ }^{5}$ Slaata og Okstad, Når kunstnere vurderer ytringsfribet $i$ Norge. Rapporten ble til som del av Fritt Ords monitorprosjekt Status for ytringsfriheten i Norge.

${ }^{6}$ Ibid., 4-5.

7 Ibid.

${ }^{8}$ Moe, «Fri ytring under press».

${ }_{9}^{9}$ Black Box teater i Oslo, BIT Teatergarasjen i Bergen og Teaterhuset Avant Garden i Trondheim.

${ }^{10} \mathrm{BIT}$, «Om oss».

${ }^{11}$ Fieldseth, Fri scenekunst i praksis, kapitel 6, 77-98. Fieldseth legger vekt på den gjensidige avhengigheten som oppstår i disse institusjonelle strukturene (se for eksempel ibid., 97), mens jeg her legger vekt på en maktubalanse.

${ }^{12}$ Jf. Fieldseth: «Programmering innebærer utvelgelse. Det vil alltid være noe som ikke passer inn i en valgt profil, eller som ikke blir sett» (ibid.).

${ }^{13}$ Se for eksempel Fieldseth, Fri scenekunst i praksis, 80; og Brauneck, Das freie Theater, 41.

${ }_{14}$ MOToffentlighet - Kunstmonstring 2016, var et prosjekt initiert av Kunstløftet. Se:

http://www.motoffentlighet.no/.

${ }^{15}$ Moe, «Fri ytring under press».

${ }^{16}$ For en detaljert beskrivelse og en næranalyse av Breiviks Erklärung se min artikkel Böhnisch, «Å gi Breivik en scene?».

${ }_{17}$ Böhnisch, «22. juli på teaterscenen?», 12.

18 Moe, «Fri ytring under press.»

${ }^{19}$ Ibid.

${ }^{20}$ Stene, «22/7: Kampen om fortellingen».

${ }^{21}$ Stenes tekst er publisert i Rushprint, et magasin for film/tv- og kinolivet i Norge og Norden. Stene skriver på vegne av et «vi, som bruker tiden vår på å skape og forstå fortellinger» (ibid.).

22 Moe, «Fri ytring under press».

${ }^{23}$ Som del av utstillingen «CaféTeatret 1971-2011 - og nu!» på Teatermuseet i Hofteatret i København.

${ }^{24}$ Situasjonen ble dessuten del av en intern konflikt mellom Johnsen og styret til Dramatikkens Hus, som ikke forble intern, men delvis eksponert offentlig.

${ }^{25}$ Se Ihler, «Min frustrasjon».

${ }^{26}$ Som da burde ses i sammenheng med den generelt meget omfattende internasjonale mediedekningen av 22. juli terroren og dens ettervirkninger. For å eksemplifisere denne medieinteressen kan vi anføre at det var 2000 representanter for 265 medier som søkte og fikk adgang til 22. juli-hovedforhandlingen i Oslo Tingrett (Oslo Tingrett, Domstolsarbeidet i 22. juli-saken, 83). 
${ }^{27}$ Manifest 2083 hadde premiere 15. oktober 2012 på CaféTeatret i København/Danmark.

${ }^{28}$ I henhold til IIPMs nettside har den i skrivende stund blitt spilt i over ti europeiske land (jf. IIPM, «Alle Projekte: Breiviks Erklärung»).

${ }^{29}$ Se mine artikler Böhnisch, «Soydans ikke-Breivik og Højgaards ikke-ikke-Breivik»; og Böhnisch, «Å gi Breivik en scene?».

${ }^{30}$ Moe, «Fri ytring under press».

${ }^{31}$ Se Böhnisch, «Soydans ikkee-Breivik og Højgaards ikke-ikke-Breivik», 38-39.

32 Moe, «Fri ytring under press»..

${ }^{33}$ Mine artikler Böhnisch, «Å gi Breivik en scene?»; Böhnisch, «Soydans ikke-Breivik og Højgaards ikkeikeke-Breivik»; og Böhnisch, «Into the Blind Spots», kan leses som eksempler på slike lesninger.

${ }^{34}$ Moe, «Fri ytring under press.»

${ }^{35}$ Interessant i denne sammenhengen er at det ikke kom noen offentlige protester da videodokumentasjonen av Manifest 2083 ble vist på dansk TV (DR2) på 2. årsdagen (22. juli 2013) til terrorangrepet.

${ }^{36}$ Balme, The Theatrical Public Sphere, 17.

37 Ibid., 16.

38 Jf. Lehmann, «Prädramatische und postdramatische Theater-Stimmen», 50.

39 Jf. Fischer-Lichte, Ästhetik des Performativen.

${ }^{40}$ Begrepet forestilt fellesskap, på engelsk «imagined communities», ble lansert av statsviteren Benedict Anderson i boken Imagined communities.

${ }^{41}$ Wiles, Theatre and Citizenship, 212.

42 Ibid., original kursivering.

${ }^{43}$ For en nærmere beskrivelse og analyse se min artikkel Böhnisch, «Soydans ikke-Breivik og Højgaards ikke-ikeke-Breivik».

${ }^{44}$ Balme, The Theatrical Public Sphere, 15, mine kursiveringer.

${ }^{45} \mathrm{Jf}$. Stene, «22/7: Kampen om fortellingen».

${ }^{46}$ Jf. Balme, The Theatrical Public Sphere, 15.

${ }^{47}$ Jf. Lödén, «Peace, love, depoliticasation and the domestic alien». Se også Rafoss, Terrorens kulturelle logike.

${ }^{48} \mathrm{Jf}$. Seierstad, En av oss.

${ }^{49}$ Norsk Redaktørforening, «Mener det har blitt mindre åpenhet», min kursivering.

${ }^{50}$ Idås, «Journalistenes møte med myndighetene».

51 Thorbjørnsrud \& Figenschou, «Det er en tid for alt?»

${ }^{52}$ Syse, red.

${ }^{53}$ Se for eksempel Ezzati, «Grenser for fellesskap: Mangfold og uenigheter i lys av 22. juli».

${ }^{54}$ Kolås, «Forståelsen av 22. juli», 109.

${ }^{55}$ Böhnisch, «Telling the Story of '22 July'».

${ }^{56}$ Anker \& von der Lippe, «Når terror ties i hjel».

57 The European Wergeland Centre, «Læringsressursen».

58 Utdanningsdirektoratet, A undervise i kontroversielle tema, 13. 
${ }^{59}$ Sistnevnte bilde er da også sentralt plassert i utstillingen til 22. juli senteret $\mathrm{i}$ Høyblokka $\mathrm{i}$

Regjeringskvartalet (Oslo). Fotografiet dekker endeveggen til det siste rommet, det vil si, det er det siste man ser, før man forlater utstillingen.

${ }^{60} \mathrm{Jf}$. Brauneck, Das freie Theater im Europa der Gegenwart.

${ }^{61}$ Vennerød, Ikkje direkte råka.

62 Points of Pain hadde en offentlig prøvevisning på Dramatikkens Hus i Oslo, 2. mai 2014.

${ }^{63}$ Som kjent, er teateret den eneste kunstformen hvor bygget det vises i, har samme betegnelse som selve kunstarten. Denne koblingen mister man når man bruker scenekunst-begrepet - det er, i mine øyne, en av grunnene til at vi burde holde fast ved et (åpent) teatenbegrep som kan brukes synonymt med scenekunstbegrepet.

${ }^{64}$ Se min analyse av Ikkje direkte råka i Böhnisch, «Into the Blind Spots», 161-170.

${ }_{65} \mathrm{Jf}$. Utdanningsdirektoratet, A undervise i kontroversielle tema.

${ }^{66}$ Balme, The Theatrical Public Sphere, 36-37.

${ }^{67} \mathrm{Jr}$. Moe, «Fri ytring under press». 


\section{Bibliografi}

Anderson, Benedict. Imagined communities: Reflections on the origin and spread of nationalism [revidert utgave]. London: Verso, 2006 [1983].

Anker, Trine og Marie von der Lippe. «Når terror ties i hjel: En diskusjon om 22. juli og demokratisk medborgerskap i skolen». Norsk pedagogisk tidsskrift 99, nr. 2 (2015): 85-96. https://www.idunn.no/npt/2015/02/naar terror ties i hjel _en_diskusjon_om_22_juli_og_demokr

Balme, Christoffer B. The Theatrical Public Sphere. Cambridge: Cambridge University Press, 2014.

BIT Bergen Internasjonale Teater. «Om oss». Hentet 12. november 2017 fra http://bitteatergarasjen.no/om-oss

Brauneck, Manfred og Das ITI Zentrum Deutschland, red. Das freie Theater im Europa der Gegenwart: Strukturen - Ästhetik - Kulturpolitik. Bielefeld: Transcript, 2016.

Böhnisch, Siemke. «Into the Blind Spots: Theatrical Approaches to the Terror Attacks in Norway 22 July 2011». European Journal of Scandinavian Studies 46, nr. 1 (2016): 157-179. DOI: https://doi.org/10.1515/ejss-2016-0010

— «Telling the Story of '22 July': A Dramaturgical Analysis of the 22 July Centre Exhibition». Conference Paper. SASS Annual Conference 2016 - Circulations. New Orleans: Society for the Advancement of Scandinavian Study. 28.-30. april 2016.

— «Soydans ikkee-Breivik og Højgaards ikke-ikke-Breivik: 22. juli i et dokumentarteaterperspektiv». Peripeti. Tidsskrift for dramaturgiske studier, nr. 21 (2014): 3648 .

— «Å gi Breivik en scene? Scenekunst etter 22.juli: Med en næranalyse av Milo Raus 'Breiviks Erklärung'». Ekfrase. Nordisk tidsskrift for visuell kultur 5, nr. 1 (2014): 17-34. [En lett forkortet versjon av denne artikkelen ble publisert 30. juni 2015 på Morgenbladets tidsskriftportal, URL: https://morgenbladet.no/2015/06/gi-breivik-en-teaterscene ]

— «22. juli på teaterscenen?» DRAMA. Nordisk dramapedagogisk tidsskrift, nr. 3 (2013): 10-13.

Ezzati, Rojan Tordhol. «Grenser for fellesskap: Mangfold og uenigheter i lys av 22. juli». Kapittel 3 i Norge etter 22. juli: Forbandlinger om verdier, identiteter og et motstandsdylktig samfunn, redigert av Henrik Syse, 47-65. Oslo: Cappelen Damm Akademisk, 2018. DOI: https://doi.org/10.23865/noasp.37.ch3

Fieldseth, Melanie. Fri scenekunst i praksis: Utviklingen av fri scenekunst i Norge på 2000-tallet. Oslo: Kulturrådet, 2015.

Fischer-Lichte, Erika. Ästhetik des Performativen. Frankfurt am Main: Suhrkamp, 2004.

Idås, Trond. «Journalistenes møte med myndighetene etter 22. juli: Demokrati, åpenhet og tilgjengelighet?» Presentasjon på Pressefribetens dag 3. mai 2012. Hentet 5. oktober 2018 fra https://www.nored.no/Redaktoernyheter/Mener-det-har-blitt-mindre-aapenhet-etter22.-juli 
Ihler, Bjørn. «Min frustrasjon». Aftenposten 6.februar 2012. Hentet 17. september 2013 fra http://www.aftenposten.no/meninger/Min-frustrasjon6756543.html?fb ref=.TzAXU4dPcqc.like\&fb source=home multiline\#.UjmwuyhwZr D

IIPM. «Alle Projekte: Breiviks Erklärung». Hentet 5. mai 2018 fra http://internationalinstitute.de/you-will-not-like-what-comes-aft'1er-america/

Kolås, Åshild. «Forståelsen av 22. juli». Kapittel 6 i Norge etter 22. juli: Forhandlinger om verdier, identiteter og et motstandsdyktig samfunn, redigert av Henrik Syse, 109-125. Oslo: Cappelen Damm Akademisk, 2018. DOI: https://doi.org/10.23865/noasp.37.ch6

Lehmann, Hans-Thies. «Prädramatische Theater-Stimmen: Zur Erfahrung der Stimme in der Live-Performance». I Kunst-Stimmen, redigert av Doris Kollesch og Jenny Schrödl, 40-66. Berlin: Theater der Zeit, 2004.

Lödén, Hans. «Peace, love, depoliticasation and the domestic alien: national identity in the memorial messages collected after the terror attacks in Norway 22 July 2011». National Identities 16, nr. 2 (2014): 157-176. DOI: https://doi.org/10.1080/14608944.2014.918593

Moe, Jon Refsdal. «Fri ytring under press». Norsk teater- og orkesterforening. Publisert 16. november 2015, hentet 5. januar 2016 fra http://www.nto.no/Presserom/NTO-skrift/Fri-ytringunder-press [gjenpublisert 18. november 2015 som debattartikkel på Scenekunst.no, http://www.scenekunst.no/sak/fri-ytring-under-press/]

Norsk Redaktørforening. «Mener det har blitt mindre åpenhet etter 22. juli». Publisert 3. mai 2012, hentet 5. oktober 2018 fra https://www.nored.no/Redaktoernyheter/Mener-dethar-blitt-mindre-aapenhet-etter-22.-juli

Oslo Tingrett. Domstolsarbeidet i 22. juli-saken: Erfaringsrapport. Oslo: Oslo Tingrett, 2013. https://www.domstol.no/globalassets/upload/obyr/internett/domstol.no-227/evalueringsrapport-2013-liten-str.pdf

Rafoss, Tore Witsøe. Terrorens kulturelle logike. Det offentlige ordskiftet etter 22. Juli. Ph.d.-avhandling. Oslo: Det samfunnsvitenskapelige Fakultet, Universitetet i Oslo, 2016. https://www.duo.uio.no/handle/10852/50236

Seierstad, Åsne. En av oss: En fortelling om Norge. Oslo: Kagge, 2013.

Slaatta, Tore og Hanne M. Okstad. Når kunstnere vurderer ytringsfribet $i$ Norge, anno 2014. Oslo: Institutt for samfunnsforskning, 2014. http://www.frittord.no/images/uploads/files/N\%C3\%A $5 \mathrm{r}$ kunstnere vurderer ytringsf rihet.pdf

Stene, Øystein. «22/7: Kampen om fortellingen». Publisert 26. juli 2011, hentet 14. november 2017 fra http://rushprint.no/2011/7/227-kampen-om-fortellingen/

Syse, Henrik, red. Norge etter 22. juli: Forhandlinger om verdier, identiteter og et motstandsdyktig samfunn. Oslo: Cappelen Damm Akademisk, 2018. DOI: https://doi.org/10.23865/noasp.37

The European Wergeland Centre. «Læringsressurser.» Hentet 5. oktober 2018 fra http://nor.theewc.org/Content/Hva-vi-gjoer/22.-juli-og-demokratiskmedborgerskap/Laeringsressurser 
Thorbjørnsrud, Kjersti og Tine Ustad Figenschou. «Det er en tid for alt? Norsk mediedebatt i året etter 22. juli». Kapittel 4 i Norge etter 22. juli: Forbandlinger om verdier, identiteter og et motstandsdyktig samfunn, redigert av Henrik Syse, 67-83. Oslo: Cappelen Damm Akademisk, 2018. DOI: https://doi.org/10.23865/noasp.37.ch4

Utdanningsdirektoratet. A undervise $i$ kontroversielle tema: Undervisning $i$ kontroversielle tema gjennom opplaring $i$ demokratisk medborgerskap og menneskerettigheter (EDC/HRE). Laringsressurs for larere. 2017. https://rm.coe.int/a-undervise-i-kontroversielle-tema/1680748448

Vennerød, Maria Tryti. Ikkje direkte råka. Dagbok 16/4-22/6 2012. Her er alt i ein post, kronologisk. Weblog. Hentet 1. juni 2018 fra https://www.forlagsliv.no/ikkjedirekteraaka/2012/06/29/ikkje-direkte-raka-dagbok-164226-2012-her-er-alt-i-ein-post-kronologisk/

Wiles, David. Theatre and Citizenship: The History of a Practice. Cambridge: Cambridge University Press, 2011.

\section{Forestillinger/sceniske prosjekter}

22. juli-lesningen. Dramaturg: Kristian Lykkeslet Strømskag. Premiere [engangshendelse] 19. oktober 2013, Saksprosafestivalen, Litteraturhuset, Oslo. [Sett 19. oktober 2013 på Litteraturhuset i Oslo.]

Blaue, Julian. Scenefilosofisk fakultet for kunstbasert terrorforskning. Premiere [engangshendelse] 16. mars 2014, Hennie Onstad Kunstsenter: Oslo. [Sett 16. mars 2014 på Hennie Onstad Kunstsenter i Oslo.]

Lollike, Christian / CaféTeateret. Manifest 2083. Premiere 15. oktober 2012, CaféTeateret: København. [Sett 16., 18. og 19. oktober 2012 på CaféTeateret i København; 28. oktober 2012 på Dramatikkens Hus i Oslo; og 10. og 11. september 2014 på Bastardfestivalen $\mathrm{i}$ Trondheim.]

Pendry, Kate / Dramatikkens Hus. Points of Pain. Premiere mai 2014 på ytringsfrihetsfestivalen Red Zone - Free the Arts: Beirut.

Rau, Milo / Campo \& International Institute of Political Murder. Five Easy Pieces. Premiere 14. Mai 2016, Kunstenfestivaldesarts: Brüssel.

Rau, Milo / International Institute of Political Murder. Hate Radio. Premiere 1. desember 2011, HAU - Hebbel am Ufer: Berlin. [Sett 20. mars 2013 på Oslo Internationale Teaterfestival, Black Box teater i Oslo.]

Rau, Milo / International Institute of Political Murder. Breiviks Erklärung. Premiere 19. oktober 2012, Lichthaus Kino: Weimar. [Sett 27. oktober 2012 ved monologfestivalen Jenseits von Gut und Böse på TeaterDiscounter i Berlin; samt 18. juni 2013 ved teaterfestivalen Jetat! Neues Dokumentartheater aus Europa på Johannes Gutenberg-Universität i Mainz.]

Vennerød, Maria Tryti / Cappelen Damm og Dramatikkens Hus. Ikkje direkte råka. Serie iscenesatte lesninger [engangshendelser], spilleperiode 26. april - 22. juni 2012, Halvbroren Bokhandel: Oslo. Involverte regissører: Kai Johnsen, Ole Johan Skjelbred, De Utvalgte, Gjertrud Jynge og Kirsti Stubø, Jon Tombre og Trine Falch. 